\title{
A CASE OF CEREBRAL AMOEBIC ABSCESS TREATED BY MODERN CHEMOTHERAPY
}

\author{
BY \\ E. A. TURNER \\ (RECEIVED JUNE 9, 1948)
}

The following case history is presented for two reasons. A case of cerebral amœbic abscess is comparatively rare in itself : Stein and Kazan in 1942 described the sixtieth case reported in the literature at that time. In only fifteen of these sixty were amœbæ actually seen in the contents of the abscesses. Secondly, this case presents unusual and fresh features in that it was treated by penicillin in addition to surgery and sulphonamides, and that the duration of the illness extended for four and a half months, far beyond the usual maximum duration of ten to fifteen days. Had anti-amœbic treatment been given at the outset of treatment for the cerebral abscess even the ultimate fatal result might have been different. It is open to speculation whether cerebral amœbic abscess may not sometimes be curable with modern chemotherapy. All the published cases to date have ended fatally.

\section{Case Report}

The patient, aged 20 years, had served in the Army for one year, nine weeks of which were spent in India. No details of service in any other country where amœbiasis is endemic are known. He was admitted to a Military Hospital in India on Feb. 6, 1946, with a two days' history of headache, pain behind the eyes, fever, and constipation. No abnormal signs were found on admission except for pyrexia. Three days later the headache became more severe, and two small bright red macules were noticed on the dorsum of the right hand. Similar macules appeared next day on the face, arms, chest, and abdomen, and were accompanied then by nuchal rigidity and a positive Kernig's sign. Next day, that is seven days after admission, the patient had a mild rigor and developed a dry cough and dyspnœa. This was followed by epistaxis, pain in the chest, and dullness and bronchial breathing at the bases of both lungs.

On admission the white blood cell count was 16,000 per c.mm. of blood (polymorphs 75 per cent., lymphocytes 19 per cent., monocytes 5 per cent., eosinophils 1 per cent.). The cerebrospinal fluid on Feb. 11 was clear, without increase of cells : protein was $55 \mathrm{mg}$. per 100 c.cm., globulin slightly increased, sugar and chlorides normal. The pressure was not measured. Blood culture was sterile. The urine was clear and contained no blood cells in the deposit.

G
On Feb. 14 the white blood cells numbered 24,000 per c.mm. of blood (polymorphs 85 per cent., lymphocytes 11 per cent., monocytes 4 per cent.). Intramuscular injections of sodium penicillin were begun, 20,000 units being given every three hours.

On Feb. 15 it was noticed that the patient was dysphasic. This disability was severe even on that day, as he could say only a few monosyllabic words in addition to "yes" and " no." He could understand simple commands but quickly perseverated. He had weakness of the right face and arm, and to a less extent of the right leg. The right plantar reflex was indefinite. He gradually became worse, without any dramatic change in the signs, until on Feb. 25 he was stuporose. A radiograph of the skull showed no abnormality. The chest at that time had radiological evidence of consolidation at the right base, with a raised right diaphragm. Papillœdema was noted. The cerebrospinal fluid pressure was $380 \mathrm{~mm}$.

On Feb. 26 a left temporal incision and burr hole were made, and an abscess cavity located in the brain at a depth of $1 \mathrm{~cm}$.; $8 \mathrm{c.cm}$. of pus was removed, and penicillin inserted. A course of general chemotherapy was given: penicillin 30,000 units three-hourly, and sulphamezathine $5 \mathrm{~g}$. followed by $3 \mathrm{~g}$. four-hourly.

By Feb. 27 he had deteriorated until the only word he could say was "yes." He had developed a bilateral sixth and a partial left third cranial nerve palsy. Bilateral burr holes were made, showing normal cortex. The right ventricle was tapped, the fluid being clear and colourless. The previous subdural operation site was re-explored and drained freely, with insertion of penicillin. Thereafter the patient improved somewhat, but did not lose completely any of the abnormal signs. The cerebrospinal fluid protein was $90 \mathrm{mg}$. per $100 \mathrm{c.cm}$., globulin increased, white cells 7 per c.mm., Wassermann reaction negative, Lange 1111000000 .

On March 1 chains of streptococci were seen in a direct smear of the pus. No organisms, however, were grown on culture, either ærobically or anærobically. The failure to culture the organisms may have been due to the fact that no paraminobenzoic acid was available to inhibit the sulphonamides, which were presumably present in the pus from the course of chemotherapy which had been commenced three days previousty.

During the next few weeks he alternately improved and relapsed. The first course of chemotherapy was stopped on March 18, by which date he had been given 5 million units of penicillin and $378 \mathrm{~g}$. of sulphamezathine. 
On March 25 the maculo-papular rash recurred, and that same afternoon his condition deteriorated again. The rash subsequently became vesicular. He was again given sulphamezathine and penicillin.

Ventriculography on March 27 showed a block between the two ventricles and a marked generalized shift to the right. Exploration of the left hemisphere yielded negative results until the needle finally entered a firm-walled abscess cavity flattened against the left side of the falx posteriorly : this was outlined by injection of thorotrast. The pus showed no organisms on direct smear, and was sterile on culture; $100 \mathrm{c.cm}$. was removed on the first occasion, and $15 \mathrm{c.cm}$. two days later.

Next month nuchal rigidity became marked and pyrexia returned. On April 12 coarse tremor and involuntary twitching were noted in the muscles of the face and upper limbs. This was taken to be tetany. Sulphonamides and alkalis were therefore stopped, and calcium gluconate was given, but without benefit. In the light of subsequent events it seems that this muscular twitching was probably due to ventricular irritation, as it is commonly seen in cases of ventriculitis.

On April 17 a large collection of cerebrospinal fluid was tapped from the front of the temporal lobe at a - depth of $6 \mathrm{~cm}$.; $55 \mathrm{c.cm}$. was allowed to escape. This contained $80 \mathrm{mg}$. of protein per $100 \mathrm{c} . \mathrm{cm}$. and 15 cells per c.mm. : globulin was not increased.

Subsequent lumbar punctures in May showed variable results, the cerebrospinal fluid being one day opalescent, one day clear. The pressure, however, remained consistently high, varying from $250 \mathrm{~mm}$. to $400 \mathrm{~mm}$.

At this stage the patient came under my care. The white blood cell count was 12,500 per c.mm. of blood. He was still having systemic chemotherapy, plus daily intrathecal penicillin. On May 9 an intracerebral abscess was tapped in the left temporal lobe, $30 \mathrm{c.cm}$. of pus being removed. This abscess was drained by tubes. The pus proved to be sterile.

On May 13 the brain was tapped again, and a second intracerebral abscess entered behind the first. The pus was at first thin and watery but later became thick and mucoid ; $50 \mathrm{c.cm}$. was aspirated. - Examination of this pus revealed no organisms. Protozoa were looked for in a wet smear, and large mononuclear cells were seen which resembled precystic forms of amœbæ but were not mobile.

A full subtemporal decompression was performed on the same day, the bone flap being removed. A specimen of pus was sent warm for immediate examination, and numerous vegetative amoba, actively mobile, were seen in the first slide. Some of these contained red blood cells, some only inclusion bodies. They were identified by the pathologist as Entameeba histolytica.

The patient was put on a course of emetine gr. 1 daily for ten days. A brisk reaction followed the exhibition of this drug. The decompression began to swell. On May 18 a further $70 \mathrm{c.cm}$. of pus was aspirated from the two abscesses. At that time it was noted that the amount of pressure in each abscess could be assessed roughly according to the nature of the dysphasiawhether it was predominantly motor or predominantly sensory. Even towards the end of the illness the patient did not completely lose the power of the right leg, arm, or face. Although drowsy when his intra-cerebral pressure was high, he became much less so as soon as pressure was relieved, and then he could still understand simple commands and utter a few simple words.

Each cavity was gently irrigated with $\mathbf{0 . 2}$ per cent. emetine hydrochloride solution in sterile water, and 10,000 units of penicillin and $1 \mathrm{c} . \mathrm{cm}$. of thorotrast were left in the abscess. Thorotrast is reported to have no deleterious effect on the potency of penicillin (Pennybacker, 1945).

On May 20 it was noted that the patient had a Horner's syndrome on the left side, with a small pupil and redness of the left face-and conjunctiva. During the next few days every site which had ever produced pus, except that next to the falx, produced yellow or "anchovy sauce" type of purulent discharge.

A culture taken on May 23 produced a growth of alarming significance-a non-hæmolytic streptococcus which was penicillin-resistant. The second prolonged course of penicillin was stopped and he was given streptomycin both intramuscularly and intrathecally $(10,000$ units): On May 30 a second course of eight emétine injections was begun. On June 2 he showed a left palatal pálsy, hoarseness, and difficulty in swallowing. Next day the white blood cell count revealed a disturbing drop to 3,400 per c.mm. of blood (polymorphs 55 per cent.). All sulphonamides were therefore stopped and were not given again. A week later the white blood cells had risen steadily to 12,300 per c.mm. (polymorphs 72 per cent.), and three days after that the white blood cells were 23,600 per c.mm. with 81 per cent. of polymorphs. His decompression continued to enlarge.

Since the situation was desperate, a desperate remedy was tried, and the whole abscess area in the left temporal region was marsupialized. Through this cerebral fungus there extruded at various times six firm encapsulated abscesses. Alternate courses of streptomycin and penicillin were continued. Neck retraction became very. marked. On June 29 it was obvious that the fungus communicated with the ventricle. The lumbar spinal fluid pressure, which had been at $180-200$, fell to below $100 \mathrm{~mm}$. Next day he died.

Necropsy.-The brain showed a widespread meningoencephalitis with the left hemisphere riddled with abscesses of varying sizes. Round these cavities was a firm grey or pink tissue resembling granulation tissue. The space between the spinal cord and the dura at the foramen magnum was filled by a firm felt of grey granulation tissue, forming a thick tube round the cord. This tissue extended over the front of the pons and midbrain and up to the pituitary region.

The only visible abnormalities elsewhere in the body were abscesses of the lower lobe of the right lung, with thickened pleura over the right base.

Histological sections were reported on by Major $L$. Krainer, R.A.M.C. :

Section of abscess wall (of the brain) showed the lumen of the abscess to be full of pus. The pus cells were degenerating polymorphonuclear leucocytes. The wall 
of the abscess showed softening and granulation, with thrombosing capillaries. Gram stain revealed groups of cocci in chains in the pus. There were omononuclear cells with foamy protoplasm, some of which contained red blood corpuscles. Heidenhain stain shows that these were Gitter cells. There was no evidence of amœbæ in the section examined.

Sections of the spleen showed reticulum cell hyperplasia of the pulp. There were central fatty change of the lobules of the liver. The tubular epithelium of the kidney was granular, and the tubules distended. No abnormality was detected in the pancreas. A section of the lung showed bronchitis, bronchiolitis, peri-bronchitis, and an area of old unresolved pneumonia with small abscesses containing polymorphonuclears. Gram stain showed scanty gram-positive cocci, single, in pairs, clumps, and short chains in the affected areas.

Central Nervous System.-There was an encapsulated abscess the size of an orange in the base of the left frontal lobe, and a collapsed abscess cavity in the left parietotemporal region corresponding to the area of operation which communicated with the left lateral ventricle. The ventricles contained thick, greenish pus, and there was severe basal meningitis.

Histological examination of four sections from the abscesses and from the basal meninges showed suppurative inflammation with numerous polymorphonuclear cells. Nucleated and degenerated Gitter cells were seen in fair numbers. Some of the degenerated Gitter cells showed shadows of nuclei, but these were not of the type seen in the vegetative amœba.

Diagnosis.--There was histological and circumstantial evidence that the cerebral abscesses were secondary to unresolved pneumonia with abscess formation in the lung. (From the clinical point of view it is of interest that septic spots appeared in the skin at the onset of the cerebral condition. No amœbæ were seen in the material examined.)

\section{Discussion}

In view of the treatment with emetine totalling 18 grains, it is not surprising that no amœbæ were found in the brain abscesses at necropsy. The comparative absence of blockage of cerebrospinal fluid circulation in spite of long-standing basal meningitis is noteworthy. It seems probable that the streptococcus found on March 1 had been present from the beginning along with the amœbæ. What would section of one of the skin papules have revealed?

The absence of a history of diarrhœa or of bowel lesions at necropsy is worthy of comment, and there it seems likely that the lung abscess played a part in the pathological picture from an early stage.

Prolonged discussion of a single case affords little profit, but the following points are worthy of note.
1. Whenever a brain abscess is tapped in a part of the world where entamœba histolytica is endemic, the fresh pus should be examined for protozoa.

2. Even in an early case treatment should include (a) radical surgical intervention, (b) emetine, and (c) anti-pyogenic chemotherapy.

The week following the exhibition of emetine should be one of constant observation and readiness to drain and decompress as circumstances indicate. At the same time infection from a secondary pyogenic invader should be treated as a meningoencephalitis of the most virulent kind, and should be dealt with on the lines suggested for pneumococcal, streptococcal, or staphylococcal meningitis following aural sepsis (Smith, Duthie, and Cairns, 1946 ; Smith, Schiller, and Cairns, 1946). It is probably unwise to use emetine locally in the treatment of the abscesses, in view of the brisk reaction which followed in this case.

\section{Summary}

A case of amœbic abscesses in the brain is described. The cerebral illness lasted four and a half months and ended fatally. Treatment with sulphonamides, penicillin, streptomycin, and emetine was given but the emetine was administered for the first time three months after the illness began. Agranulocytosis necessitated cessation of the sulphonamide therapy after fourteen weeks.

The unusually long period of survival in this case suggests that if modern chemotherapy is given early a cure may be obtainable; the lines along which early treatment might be directed are outlined.

Thanks are due to Capt. N. M. Nair, I.A.M.C., and Major L. Krainer, R.A.M.C., who were responsible for the pathologica lreports on the smears and later on the sections. I am indebted also to Lt.-Col. A. J. Slessor, Major R. H. Hannah, Capt. W. J. Connolly, and Capt. O. M. Brewster, R.A.M.C., from whose comprehensive notes it has been possible to determine the early history. With particular pleasure, acknowledgment is made to Major W. J. Woodhouse, I.A.M.C., Specialist Radiologist, but for whose suggestion the original examination for amœbæ would not have been made.

I am also indebted to Colonel E. Percival, R.A.M.C., for permission to forward this case for publication.

\section{REFERENCES}

Pennybacker, J. (1945). Proc. ;oy. Soc. Med., 38, 431. Smith, H. V., Duthie, E. S., and Cairns, H. (1946). Lancet, 1, 185.

, Schiller, F., and Cairns, H. (1946). Proc. roy. Soc. Med., 39, 613.

Stein, A., and Kazan, A. (1942). J. Neuropath. exp. Neurol., 1, 32. 